Shamayim: Jurnal Teologi dan Pendidikan Kristiani

Volume 1, Nomor 1, 2020 (29-44)

http://hologos.college/ejournal/index.php/shamayim/index

\title{
Peranan Orang Tua Dalam Pendidikan Agama Kristen Terhadap Pertumbuhan Rohani Anak
}

\author{
Semuel Ruddy Angkouw \\ Sekolah Tinggi Alkitab Batu \\ semuelangkouw@stabatu.ac.id \\ Simon \\ Sekolah Tinggi Teologi Salatiga \\ simonpetrus45144@gmail.com
}

\begin{abstract}
Parents who are given a mandate by God to be the main spiritual educators for their children. The purpose of God is to encourage parents as the main spiritual educators for their children, so that their children will experience spiritual growth in their faith in Him. This paper discusses the role of parents in Christian religious education on children's spiritual growth. The method used in this writing is a quantitative method with a questionnaire approach accompanied by descriptions of the answers of the respondents to the questionnaires that were distributed. The findings of this study are the respondents, in this case the church Gereja Pantekosta di Indonesia (GPdI) Glenmore Kabupaten Banyuwangi, carry out its role as a parent in cultivating Christian values for the spiritual growth of children although not significantly overall.
\end{abstract}

Key words: Spiritual Growth, Congregation, Christian Education.

\begin{abstract}
Abstrak
Orang tua diberikan mandat oleh Allah untuk menjadi tenaga pendidik kerohanian yang utama bagi anak-anaknya. Tujuan Allah menghimbau orang tua sebagai pendidik kerohanian utama bagi anak, agar kerohanian anak mengalami pertumbuhan secara iman kepada-Nya. Tulisan ini membahas tentang peran orang tua dalam pendidikan agama Kristen terhadap pertumbuhan kerohanian anak. Metode yang digunakan dalam penulisan ini adalah metode kuantitatif dengan pendekatan angket disertai pendeskrifsian jawaban para responden atas angket yang dibagikan. Temuan dari penelitian ini adalah para respoden dalam hal ini jemaat Gereja Pantekosta di Indonesia (GPdI) Glenmore Kabupaten Banyuwangi, melaksanakan perannya sebagai orang tua dalam penanaman nilai-nilai
\end{abstract}


kekristenan untuk pertumbuhan kerohanian anak walau tidak secara signifikan secara keseluruhan.

Kata kunci: Pertumbuhan Rohani, Jemaat, Pendidikan Agama Kristen

\section{Pendahuluan}

Pertumbuhan kerohanian anak ditentukan dengan adanya penanaman nilai-nilai spiritual yang dilakukan oleh kedua orang tua yaitu ayah dan ibu. Orang tua tidak boleh hanya mengharapkan anak mereka mendapatkan penanaman nilai-nilai kerohanian di gereja, tetapi mereka juga dituntut sebagai tenaga pendidik agar terjadi pertumbuhan iman anak kepada Tuhan Yesus Kristus. Sering sekali orang tua menyerahkan pertumbuhan kerohanian anak mereka kepada pendeta, penatua atau pengurus gereja, padahal orang tualah sebagai guru utama anak mengalami peningkatan kerohanian. Tafonao mengemukakan bahwa pendidikan Agama Kristen dalam keluarga sangat penting diterapkan oleh orang tua di zaman sekarang. Salah satu peran pendidikan Agama Kristen dalam keluarga saat ini adalah mengupayakan kerjasama ayah dan ibu dalam mendidik anak serta menciptakan keharmonisan dalam keluarga. Oleh karena itu, keluarga merupakan lingkungan yang paling utama dalam melakukan pembentukan sosial kepada anak-anak. ${ }^{1}$ Sejalan dengan itu, pendapat senada dikemukakan oleh Metboki, bahwa orang tua memiliki peran dalam membentukan karakter dan kerohanian anak. Karena itu orang tua sebagai pemilik anak yang sesungguhnya memiliki tanggung jawab yang sangat besar dalam pembentukan karakter dan kerohaniannya agar selaras dengan firman Alah. ${ }^{2}$

Tanggung jawab yang Allah berikan kepada orang tua mengenai pertumbuhan kerohanian anak, sudah sepatutnya orang tua tidak melalaikan peran mereka sebagai pendidik untuk kemajuan kerohanian anak-anaknya. Karena dengan menjalankan fungsinya sebagai orang tua yang menididik anggota keluarganya akan nilai-nilai kekristenan, maka ia telah melaksanakan perintah Allah yang mengungkapkan agar mengajarkan titah-titah Allah. Alkitab Penuntun Hidup Berkelimpahan menguraikan beberapa tugas orangtua untuk menuntun anaknya menuju kehidupan yang saleh di dalam Kristus, yakni: Mengajar anak-anak agar takut akan Tuhan; mengajar anak-anak untuk menaati orangtua; melindungi anak-anak dari berbagai pengaruh jahat; menyadarkan anakanak bahwa Allah selalu melihat setiap orang yang berbuat baik dan jahat; mengajar anakanak bahwa Allah mengasihi setiap orang. ${ }^{3}$

Oleh sebab itu pendidikan agama Kristen di tengah-tengah keluarga Kristen dalam masyarakat memegang peranan yang sangat penting. Perubahan yang terus menerus dalam

1 Talizaro Tafonao, "PERAN PENDIDIKAN AGAMA KRISTEN DALAM KELUARGA TERHADAP PERILAKU ANAK," Edudikara: Jurnal Pendidikan dan Pembelajaran 3, no. 2 (2018): 121.

${ }^{2}$ Rianto J. A. Metboki, "Peranan Orangtua Kristen Dalam Membentuk Karakter Anak," SESAWI: Jurnal Teologi dan Pendidikan Kristen 1, no. 2 (2020): 56.

3 “Alkitab Penuntun Hidup Berkelimpahan” (Malang: Gandum Mas, 2000), 1994. 
tata nilai masyarakat berdampak luas dalam kehidupan keluarga-keluarga dan individu. Karena itu keluarga-keluarga membutuhkan suatu sistem penyaringan untuk dapat menangkal dampak negatif perubahan dalam nilai- nilai masyarakat. Di sinilah para orang tua memegang peranan yang sangat penting bagi pertumbuhan anak. Apabila anak tidak memiliki tingkat kerohanian yang benar, maka anak tersebut akan terbawa oleh arus perubahan dunia yang sangat cepat tersebut khususnya perubahan dalam hal negatif. Orang tua dalam hal ini adalah ayah dan ibu. Josh dalam penelitiannya menemukan ada tiga dampak yang dialami bila orang tua tidak hadir dalam keterlibatan pertumbuhan kerohanian anak. Pertama, ayah yang absen secara emosional atau fisik atau tidak memberi kontribusi kepada anak maka motivasi anak akan rendah untuk berprestasi. Kedua, anak berpotensi harga dirinya rendah, dan ketiga anak rentan pada pengaruh dari kelompok kenakalan atau dari lingkungan yang negatif. ${ }^{4}$

Keterlibatan orang tua terhadap pertumbuhan kerohanian anak harus diupayakan dimulai dari usia dini. Karena usia dinilah anak-anak dengan mudah ditanamankan nilainilai kebenaran firman Tuhan. Orang tua harus berperan sebagai pendidik agar kerohanian anak semakin bertumbuh kearah yang dikehendaki oleh Tuhan. Tujuan dari tulisan ini untuk menekankan bahwa betapa pentingnya orang tua berperan sebagai pendidik agama Kristen bagi kemajuan kerohanian keluarga dalam hal ini anak-anak.

\section{Metode Penelitian}

Menurut Dedy Mulyana metode adalah proses, prinsip dan prosedur yang digunakan untuk suatu pendekatan dalam mengkaji topik penelitian hingga mencari jawaban. ${ }^{5}$ Dalam penulisan artikel ini metode yang peneliti gunakan adalah metode kuantittatif dengan pendekatan deskriftif, yaitu jenis penelitian yang bertujuan menggambarkan secara tepat sifat-sifat suatu individu, keadaan, gejala atau kelompok tertentu atau untuk menentukan frekuensi atau penyebaran suatu gejala atau frekuensi adanya hubungan tertentu antara suatu gejala dan gejala lain dalam masyarakat. ${ }^{6}$ Penelitian ini dilakukan di Gereja Pantekosta di Indonesia Glenmore Kabupaten Banyuwangi. Jumlah responden yang diteliti dalam tulisan ini 40 orang.

Prosederual dalam pelaksaannya dimulai dari menganalisis dengan tujuan membahas secara evaluatif pertanyaan mengapa suatu sistem tidak beroprasi atau bagaimana meningkatkan operasi sistem itu. Dalam hal ini akan dipakai sebagai bahasan secara evaluatif atas pertanyaan-pertanyaan dalam kuesioner. Analisis dilakukan dengan cara menyoroti penemuan-penemuan dengan cara kembali ke data-data tertentu, yang sudah disajikan, supaya lebih tajam dan terperinci. Deskripsi akan dilakukan kerangka kerja analisis yang telah ditetapkan. ${ }^{7}$ Langkah-langkah dalam pengolahan data adalah sebagai berikut, membuat tabel jawaban partisipan. Kemudian pengolaan dengan operasi

\footnotetext{
${ }^{4}$ Josh Mc Dwell, The Father Conecnection (Jakarta: Metanonia Publishing, 2004), 6.

${ }^{5}$ Dedy Mulyana, No Metode Penelitian (Bandung: Rosdakarya, 2002), 120.

${ }^{6}$ Sugiyono, Metode Penelitian, 23rd ed. (Bandung: ALFABETA, 2016), 62.

${ }^{7}$ Sugiyono, Statistika Untuk Penelitian, Cetakan ke. (Bandung: ALFABETA, 2014), 261.
} 
matematika sederhana untuk mencari prosentase. Prosentasi didapat dengan menggunakan rumus sebagai berikut:

$$
\mathbf{P}=\mathbf{f i} / \mathbf{N} \times 100 \%
$$

$$
\begin{aligned}
& \mathrm{P}=\text { Prosentasi } \\
& \text { fi= Jumlah Partisipan dalam sebuah kategori } \\
& \mathrm{N}=\text { jumlah Partisipan }^{8}
\end{aligned}
$$

Setelah itu akan mengkategorikan dalam bentuk prosentase dengan kategori sebagai berikut:

$$
\begin{array}{ll}
\text { Rendah } & \text { : kurang dari } 40 \% \\
\text { Baik } & \text { : antara } 41-75 \% \\
\text { Baik sekali } & \text { : lebih } 76-100 \%
\end{array}
$$

Prosentase peran orang tua dalam pendidikan agama Kristen terhadap pertumbuhan rohani anak di GPdI Glenmore Banyuwangi disebut rendah jika kurang dari 40\%; baik jika berada diantara 41-75\% dan prosentase baik sekali jika berada di antara 76-100.

\section{Pembahasan dan Hasil}

\section{Peranan Orang Tua Dalam Pendidikan Agama Kristen Bagi Pertumbuhan Rohani} Anak.

Kitab Ulangan tidak hanya merupakan kisah pembaharuan perjanjian, tetapi juga adalah suatu catatan tentang amanat-amanat Musa kepada bangsa Israel. Diantara amanatamanat tersebut salah satunya adalah amanat pendidikan yang menitikberatkan pada lingkungan keluarga, seperti di tululis dalam Ulangan 6:5-7 yang menulis "Kasihilah TUHAN, Allahmu, dengan segenap hatimu dan dengan segenap jiwamu dan dengan segenap kekuatanmu. Apa yang kuperintahkan kepadamu pada hari ini haruslah engkau perhatikan, haruslah engkau mengajarkannya berulang-ulang kepada anak-anakmu dan membicarakannya apabila engkau duduk di rumahmu, apabila engkau sedang dalam perjalanan, apabila engkau berbaring dan apabila engkau bangun. Pendapat senada dikemukakan oleh Utami bahwa Kitab Ulangan 6:4-9 "Dengarlah Hai Orang Israel". Bagian ini sering kali disebut sebagai "Shema" Ibrani sahma artinya mendengar. Bagian ini sangat dikenal orang Yahudi pada zama Yesus karena diucapkan setiap hari oleh orang Yahudi yang saleh dan secara tetap dalam kebangkitan di Sinagoe. Shema ini merupakan pernyataan terbaik tentang kodrat monoteistis Allah, perintah ini diikuti dengan perintah ganda kepada bangsa Israel; (1) untuk mengasihi Allah dengan segala hati, jiwa, dan kekuatan (Ul. 6:5-6). (Ul. 6:7-9), dan (2) untuk mengajarkan iman mereka dengan tekun kepada anak-anak mereka Ul. 6:4; 11:13-21."9

\footnotetext{
${ }^{8}$ Rony Kontur, Statistik Praktis (Jakarta: PPM, 2005), 26.

9 Ninik Tri Utami, "TINJAUAN TERHADAP PRINSIP-PRINSIP PENGAJARAN ANAK BERDASARKAN ULANGAN 6:1-19,” Logon Zeos Jurnal Teologi Sosial dan Budaya 1, no. 1 (2017): 109.
} 
Tugas dan tanggungjawab tersebut harus dilakukan oleh para orang tua Israel yaitu mendidik anak-anak supaya hidup mengasihi Tuhan Allah dengan segenap jiwa dan kekuatan, di manapun dan kapanpun, dengan kata lain bahwa pendidikan agama harus diajarkan setiap waktu. Pendidikan pada masa Perjanjian Lama memiliki dasar-dasar teologis yang kuat yang merupakan pondasi bagi pertumbuhan iman umat Israel pada Tuhan. Bahkan Allah sendiri yang memerintahkan bangsa Israel untuk mengajar dan mendidik keluarga Israel. Sehingga pendidikan yang menyangkut keagamaan yang berhubungan dengan Allah menjadi nyata dalam kehidupan mereka sehari-hari. Demikian pemimpin Yahudi berkesimpulan bahwa setiap angkatan baru perlu diperkenalkan dengan warisannya. ${ }^{10}$

Pendidikan dalam masyarakat Israel dahulu adalah tugas rumah tangga. Di dalam Perjanjian Lama, tidak pernah disebut semacam sekolah apapun, sehingga sukar untuk mengetahui cara mendidik anak-anak Israel. Tentu saja mereka belajar mata pelajaran dasar seperti membaca, menulis, dan menghitung. Juga mereka diajar cara memelihara binatang dan tanaman. Setiap masyarakat memang harus menyampaikan pengetahuan demikian kepada angkatan berikut. Dugaan paling wajar dalam hal ini adalah bahwa keterampilan dan pengetahuan demikian diajarkan bukan disekolah melainkan oleh nenek moyang kepada keturunannya secara berkesinambungan. ${ }^{11}$

Perjanjian Lama menerangkan dengan sangat jelas bahwa mengajarkan agama adalah tugas rumah tangga. Tugas mendidik anak-anak mengenai kepercayaan kepada Tuhan merupakan tugas utama yang harus ditaati setiap orang tua di kalangan umat Tuhan. Umat Yahudi sendiri pada umumnya ayah, ditugaskan untuk menyampaikan kekayaan iman Yahudi kepada setiap angkatan baru. Ayah diharapkan menjadi pemrakarsa untuk mengajar anak-anak. Ayah yang taat akan menganggap tanggungjawab ini adalah suatu kehormatan. Waluyo mengemukakan peran ayah dalam pendidikan kepada anak-anak tersebut dapat dilihat melalui kitab Ulangan 6:1-9. Melalui dasar dari kebenaran Firman Tuhan tersebut maka diharapkan ayah sebagai kepala keluarga bisa berjalan sesuai Firman Tuhan dan membawa keluarganya kepada kehendak Tuhan. ${ }^{12}$

Kepentingan tugas ini dapat dilihat dengan memeriksa pengakuan iman yang paling dasar dari bangsa Israel dan peranan keluarga, khususnya orang tua, dalam menyampaikan ajaran ini kepada anak-anakanya. Bahwasanya peran pengajaran keluarga muncul dengan kekuatan besar dalam Ulangan 6:5-7. Ayat ini merupakan tuntutan supaya Israel mengabdi kepada Tuhan dengan kesetiaan total. ${ }^{13}$ Pendidikan Ibrani berpusat pada kehadiran dan penyembahan Allah yang Esa. Pendidikan Ibrani selalu menempatkan sesuatu yang bersifat vertikal pada posisi yang lebih tinggi daripada sesuatu yang bersifat horizontal, relasi kepada Allah terlebih dahulu sebelum menaruh perhatian kepada dirinya sendiri pada tingkatan kemanusiaan.

${ }^{10}$ Robert R. Boelke, Sejarah Perkembangan Dan Praktek Pendidikan Agama (Jakarta: BPK Gunung Mulia, 1998), 23.

${ }^{11}$ Keat J. Wiles, Keluarga Pada Mulanya Hingga Dalam Tuhan (Semarang: STBI, 1986), 42.

${ }^{12}$ Tri Waluyo, "Peran Ayah Dalam Pendidikan Kepada Anak Menurut Ulangan 6:1-9," Jurnal Teologi El-Shadday 7, no. 1 (2020): 36.

${ }^{13}$ I.J. Cairn, Tafsiran Alkitab Ulangan (Jakarta: BPK Gunung Mulia, 1986), 132. 
Metode pendidikan Perjanjian Lama dapat dilihat dalam ulangan 6;7 di mana orangorang Israel mengajarkan kehendak Tuhan kepada anak-anaknya dengan terus membicarakannya pada setiap saat di setiap tempat. Diharapkan orang tua selalu mengajarkan Firman Tuhan sebagai pokok pembicaraan dengan demikian anak-anak selalu belajar Firman Allah. "Setiap makan malam orang tua Israel menggunakan waktu berkumpul dengan keluarganya dan mengajarkan nilai-nilai luhur ajaran nenek moyang mereka, dengan meminta anak-anak terkecil dalam keluarga untuk menanyakan apa saja yang telah dilakukan nenek moyang mereka". ${ }^{14}$

\section{Orag Tua Sebagai Pendidik}

Keluarga (orang tua) Kristen mempunyai fungsi dan tugas antara lain "mengajar, membina, dan membimbing anak dalam mendisiplinkan diri. "Bimo Wagito mengemukakan bahwa: "keutuhan keluarga Kristen yang selalu mendisiplinkan anakanaknya selalu tercipta diantara ayah dan ibu dalam keseharian membina secara rohani; perlindungan pengertian, kasih sayang dan lain sebagainya." ${ }^{15}$ John Lock dalam teori "Tabula rasa", mengemukakan bahwa isi kejiwaan anak ketika dilahirkan adalah ibarat secarik kertas yang masih kosong. Artinya bagaimana nanti bentuk dan corak kertas tersebut bergantung pada cara kertas tersebut ditulis. ${ }^{16}$

Jadi pada saat itu dibentuk, orang tualah yang pertama membentuknya. Jika anak tersebut dibentuk dan dididik dengan ilmu pengetahuan saja, maka anak itu kurang mengahargai norma-norma agama pada depannya, karena dia akan mementingkan ilmu yang didapatnya, yang membawa kepada keuntungan diri. Untuk itu para tua sebagai pendidik dan Pembina iman anak yang pertama dan utama sangat dibutuhkan. Dalam hal ini tanggungjawab orang-orang tua harus dimaksimalkan. Pembinaan yang benar adalah pembinaan yang lengkap dan seimbang. Gereja, sekolah, pemerintah dan rumah tangga yang mendidik dan membina anak-anak dalam ilmu pengetahuan saja tidaklah ideal. Manusia yang hanya mentalnya dikembangkan akan mengalami kesukaran dalam hidup. ${ }^{17}$

Pertumbuhan yang benar tidak mengabaikan pertumbuhan rohani anak, sebab normanorma agama mutlak perlu bagi seorang anak dalam pertumbuhannya. Dalam hal ini orang tua harus membesarkan anak dalam pengetahuan dan pengenalan akan Allah. Ulangan 6:67 menjelaskan "apa yang Kuperintahkan kepadamu pada hari ini haruslah engkau perhatikan, haruslah engkau mengajarkannya berulang-ulang kepada anak-anakmu..." Perintah itu mengindentifikasikan bahwa mendidik anak harus dilaksanakan oleh setiap orang tua. Anak perlu dituntun untuk mengenal Allah Sang Pencipta dan Pemberi hidup, agar sejak dini ia belajar menghormati Allah dan menjadikan firman Allah sebagai pembaharuan dalam kehidupannya. Hal ini penting disadari oleh setiap orang tua sebab apabila mereka mencermati perkembangan dunia dewasa ini banyak sekali pembaharuan

\footnotetext{
${ }^{14}$ I.J. Cairn, 25.

${ }^{15}$ Bimo Walgito, Bimbingan Ditinjau Dari Iman Kristen (Salatiga: Fakultas Psikologi, 1973), 7.

${ }^{16}$ Singgih Gunarsa, Singgih Gunarsa Perkembangan Anak (Jakarta: BPK Gunung Mulia, 1980), 16.

${ }^{17}$ I.R. Sarumpae, Rahasia Mendidik Anak (Bandung: Indonesia Publishing House, 2001), 12.
} 
dan pergeseran nilai, sehingga banyak anak kehilangan pegangan. Tari dan Tafonao menyatakan Salah satu perilaku baik yang diperlihatkan oleh orang tua kepada anak adalah mendidik dan mengasuh anak-anaknya dengan baik. Penanaman moral bagi anak tercermin dalam sikap dan prilaku orang tua sebagai teladan yang dapat dicontoh oleh anak dan segala nilai yang dikenal anak akan melekat pada orang-orang yang disenangi dan dikaguminya, dan melalui inilah salah satu proses yang ditempuh anak dalam mengenal nilai. ${ }^{18}$

Oleh sebab itu pendidikan agama harus diterapkan dalam lingkungan keluarga untuk membentuk anak menjadi pribadi yang bermoral dan dan takut akan Allah. Pendidikan agama memberi pengaruh dalam menunjang pola hidup benar dalam dunia atau lingkunagn yang dapat merusak akhlak manusia. Pendidikan Agama perlu diterapkan sejak dini bukan hanya di gereja tetapi juga di rumah sebagai dasar pembentukan karakter dan pribadi yang hidupnya berporos pada pribadi Yesus dan Alkitab sebagai dasar hidupnya. Dalam Efesus 6:1-4 mengatakan: Hai anak-anak, taatilah orang tuamu di dalam Tuhan, karena haruslah demikian. Hormatilah ayahmu dan ibumu -- ini adalah suatu perintah yang penting, seperti yang nyata dari janji ini: supaya kamu berbahagia dan panjang umurmu di bumi. Dan kamu, bapa-bapa, janganlah bangkitkan amarah di dalam hati anak-anakmu, tetapi didiklah mereka di dalam ajaran dan nasihat Tuhan.

\section{Orang Tua Adalah Wakil Allah}

Setiap anak akan hidup dengan bangga dalam keluarga jika mereka mempunyai orang tua yang patuh dan taat kepada Allah. Anak-anak yang tidak taat atau menolak didikan orang tua, sama artinya dengan tidak patuh kepada Allah. Melalui orang tua, anakanak menerima berkat dari Allah. Anak pada saat besar, mempunyai lingkungan pergaulan yang berbeda, yaitu keluarga, sekolah dan masyarakat. Dari ketiga hal ini, yang mendasar adalah keluarga sebagai fundamen pertama dalam keluarga. Jika orang tua tidak mengajarkan anak-anak dengan baik, maka iblis dan lingkungan di luar rumah akan mendidik dia. Mengingat banyaknya pengaruh negatif dari perkembangan kehidupan modern, baik melalui tekhnologi, budaya maupun gaya hidup bebas yang dapat meruntuhkan dan menghambat pertumbuhan iman anak-anak, maka setiap orang tua hendaknya menyadari bahwa tugas untuk membina kerohanian anak-anak bukanlah tanggung jawab penuh gereja dan guru-guru sekolah, melainkan tugas bersama antara orang tua dan gereja. ${ }^{19}$

Keluarga adalah bagian penting dari sebuah gereja. Pada zaman ini adalah masa di mana keberadaan keluarga-keluarga Kristen diserang atau dirongrong. ${ }^{20}$ Tantangan itu bisa berasal dari dalam keluarga itu sendiri atau juga berasal dari luar, oleh sebab itu keluargakeluarga yang ada perlu bimbingan melalui pendidikan Kristen dalam keluarga. Dengan demikian maka mengajarkan pendidikan agama menjadi tugas bagi para orang tua, dan

\footnotetext{
${ }^{18}$ Ezra Tari \& Talizaro Tafonao, "Pendidikan Anak Dalam Keluarga Berdasarkan Kolose 3:21," KURIOS (Jurnal Teologi dan Pendidikan Agama Kristen) 5, no. 1 (2019): 36.

${ }^{19}$ Riana Udurman Sihombing \& Rahel Rati Sarungallo, "Peranan Orang Tua Dalam Mendewasakan Iman Keluarga Kristen Menurut Ulangan 6:6-9,” KERUSSO 4, no. 1 (2019): 34.

${ }^{20}$ Jhon Stott, Isu-Isu Global Edisi Revisi (Jakarta: Yayasan Komunikasi Bina Kasih, 2015), 383.
} 
mengajarkan agama harus dilakukan oleh para orang tua dimanapun dan kapanpun tanpa dibatasi oleh ruang atau waktu. Sehingga anak-anak akan menjadi orang yang hidup menurut perintah-perintah Allah, dalam kebenaran dan bertumbuh dalam hal kerohanian.

\section{Pertumbuhan Rohani Anak}

\section{Bertumbuh Dalam Pengabdian}

Setiap Orang Kristen harus bertumbuh kedua arah: berakar keabawah, akar tidak kelihatan, tetapi juga keatas, dalam aktivitas pelayanan, pengabdian, kesaksian mengikut Yesus juga harus Nampak. Pohon yang bertumbuh akarnya harus makin menghujam ke dalam tanah dan pohonnya makin rimbun. Pertumbuhan dua arah itu harus seimbang. Pertumbuhan akan abnormal apabila hanya bertumbuh satu arah. Kalau daunnya rimbun tapi akarnya pendek, apa yang terjadi? segera tumbang ketika angin topan datang. Banyak orang Kristen kelihatannya rajin, giat, aktif, tetapi motivasi dan imannya dangkal. Latif mengemukakan Alkitab memberikan 8 hal berkaitan dengan kedewasaan rohani dan tingkat pertumbuhan yang sesuai dengan kepenuhan Kristus dalam Efesus 4:13-15 dan Kisah Para Rasul 2:41-47, yaitu: Mencapai kesatuan iman; Memiliki pengetahuan yang benar tentang Kristus; Teguh berpegang kepada kebenaran; Bertumbuh dalam kasih kepada Allah dan sesama; Meningkat hubungan dengan Allah; Terjadi kesatuan antar sesama anggota jemaat; Hidup yang memberkati sesama; Berani memikul tanggung jawab dalam pelayanan. ${ }^{21}$

Saat kesulitan datang, kalau rayuan datang, cobaan bertubi-tubi dengan mudah ia tumbang. Tetapi kalau pertumbuhan itu hanya ke bawah, tidak ke atas, terjadi juga keanehan. Pohon yang akarnya sudah tua, daunnya hanya dua dari dulu, bonsai namanya. Lebih lanjut L.Z. Raprap berkata "Banyak orang Kristen tumbuh seperti bonsai. Sudah lama jadi Kristen tapi tidak bertumbuh, tidak ada kemajuan, tidak ada pengabdian yang makin meningkat, tidak ada kesetiaan melayani yang makin bertambah. Semuanya berjalan begitu saja. Sejak dibaptis

hanya tahu doa Bapa kami dan pengakuan iman"22

\section{Bertumbuh dalam Iman}

Pertumbuhan itu harus dua arah. Iman yang tidak kelihatan dan yang kelihatan adalah pelayanan, pengabdian, hal mengikut Yesus dalam keluarga, jemaat, dan masyarakat. Jadi pertumbuhan harus kedua arah supaya memiliki akar yang kuat. ${ }^{23}$ Anakanak merupakan potensi besar bagi suatu bangsa. Bukankah mereka nanti akan menjadi pemimpin dalam masyarakat, pemimpin pemerintahan, pemimpin militer, maupun pemimpin dalam perusahaan? Mereka juga akan menjadi pendeta, penginjil, majelis jemaat, pendidik dan lain-lain. Mereka adalah generasi penerus bangsa dan juga generasi

${ }^{21}$ Helen Farida Latif, "Pengaruh Pengajaran Dan Persekutuan Terhadap Tingkat Pertumbuhan Rohani Anak Dan Remaja," EPIGRAPHE: Jurnal Teologi dan Pelayanan Kristiani 1, no. 1 (2017).

${ }^{22}$ L.Z. Raprap, Seminar Pertumbuhan Gereja (Jakarta: Panitia SPG, 1989), 291.

${ }^{23}$ L.Z. Raprap, Seminar Pertumbuhan Gereja. 
penerus gereja. Anak-anak sekarang adalah pemimpin hari esok. Menurut statistik 1/3 nya adalah anak-anak dibawah usia 15 tahun. Mereka ini merupakan ladang dalam penginjilan anak-anak. Berbicara tentang pertumbuhan rohani anak, mau tidak mau akan berbicara tentang peranan orang tua. ${ }^{24}$

Tugas orang tua sebagaimana dikatakan dalam Ulangan 6:5-7 yang terkenal dengan "Shemma" yaitu tugas untuk mendidik anak-anak mereka berulangkali dengan berbagai situasi dan cara yang tepat sehingga anak mengenal Allah Pencipta, Pemelihara dan mentaati Dia. Anak dipersembahkan kepada Tuhan dididik agar sepanjang hidup melayani Allah. Orang dewasa diperintahkan untuk mendidik orang yang lebih muda (Amsal 22:6). Dr. Clarence Benson seperti yang dikutip Rona mengatakan bahwa orang-orang yang meragukan tentang perintah Allah ini sebenarnya tidak mengerti tentang kata "didik/latih". Banyak yang sudah mendengar, sebagian sudah diajarkan tetapi sedikit saja yang telah dididik/dilatih. ${ }^{25}$

Pendidikan bukan hanya satu proses tetapi penyampaian atau pemberitahuan, juga bukan hanya proses pengajaran tetapi meliputi proses didikan atau latihan. Memberitahukan artinya menolong untuk mengetahui. Mengajar artinya menolong untuk mengetahui dan bertumbuh. Didikan atau latihan artinya menolong untuk mengetahui, bertumbuh dan melakukan atau berbuat. Jadi pendidikan bukan hanya mengetahui atau mendapat sesuatu tetapi menggunakan pengetahuannya yang sudah diperoleh. ${ }^{26}$ Setiap orang tua harus memperlengkapi dirinya dengan pengetahuan rohani agar dapat memimpin anak-anak mereka kepada Kristus dan menjadi contoh bagi anak-anak mereka dalam pertumbuhan rohani.

\section{Hasil Angket}

Penelitian ini menitik beratkan pada peran orang tua dalam pendidikan agama Kristen terhadap pertumbuhan rohani anak, yaitu:

1. Peranan Ayah, meliputi ayah sebagai Imam dalam keluarga, ayah sebagai pendoa, ayah sebagai pendidik, ayah sebagai pembawa terang.

2. Peranan Ibu, meliputi ibu dalam keluarga, sebagai ibu rumah tangga, ibu sebagai sahabat anak, ibu sebagai guru, ibu sebagai pelayan.

3. Orang tua mempunyai tugas sebagai pendidik, ayah adalah wakil Allah diatas muka bumi ini.

4. Pertumbuhan rohani anak meliputi bertumbuh dalam pengabdian, bertumbuh dalam iman.

Partisipan yang diberikan angket sebanyak empat puluh orang, terdiri dari para warga dewasa (orang tua) di GPdI Glenmore Kabupaten Banyuwangi. Hasil dari data tersebut akan ditulis dan diuraikan di bawah ini sesuai dengan pengisian angket yang di dapat dari jawaban partisipan. Dari data hasil penelitian yang telah dilakukan, maka peneliti akan menyajikan deskripsi mengikuti kerangka kerja analisis yang telah

\footnotetext{
${ }^{24}$ Yos E. Rona, Peranan Anak Dalam Pertumbuhan Geraja (Jakarta: Panitia SPG, 1989), 167.

${ }^{25}$ Yos E. Rona, Peranan Anak Dalam Pertumbuhan Geraja.

26 Ibid.
} 
ditetapkan. Data-data tersebut dapat dijelaskan melalui berbagai pendapat dan bagian yang telah atau pun sedang dilakukan oleh masing-masing partisipan.

Pernyataan-pernyataan yang diberikan ada empat bagian yaitu tentang peranan oran gtua dalam pendidikan agama Kristen terhadap pertumbuhan rohani anak yaitu:

Pertama peranan Ayah, meliputi ayah sebagai Imam dalam keluarga, ayah sebagai pendoa, ayah sebagai pendidik, ayah sebagai pembawa terang. Selanjutnya yang kedua peranan Ibu, meliputi ibu dalam keluarga, sebagai ibu rumah tangga, ibu sebagai sahabat anak, ibu sebagai guru, ibu sebagai pelayan. Orang tua mempunyai tugas sebagai pendidik, ayah adalah wakil Allah diatas muka bumi ini. Dan yang ke empat pertumbuhan rohani anak meliputi bertumbuh dalam pengabdian, bertumbuh dalam iman.

Ternyata hasil yang diperoleh dari angket pernyataan yang telah dibagikan dapat terisi dengan baik. Dari setiap pernyataan mempunyai pilihan jawaban yang dapat mengarahkan para partisipan kepada tindakan-tindakan yang dilakukan mereka. Masingmasing partisipan pastinya memiliki alasan tertentu untuk memilih, baik menyetujui atau tidak menyetujui bahkan memilih ragu-ragu. Dalam angket ini, terdapat pernyataan yang bersifat positif dan negatif, namun dalam pengumpulan jawaban semua pernyataan sudah dipositifkan sehingga memudahkan penghitungan dan dapat memperoleh data yang lebih valid. Angket tersebut dibagi menjadi empat tabel sesuai dengan jumlah indikator dalam sintesis pustaka. Di samping itu juga di sertai dengan tabel-tabel lain yang mendukung validnya penelitian. Berikut adalah jawaban-jawaban yang diperoleh secara menyeluruh:

Tabel 1. Pendidikan Agama Kristen sangat penting di tengah-tengah keluarga meliputi Peranan Ayah

\begin{tabular}{|l|l|}
\hline 1 & Ayah adalah pemimpin dalam hal berhubungan dengan Allah \\
\hline 2 & Kehidupan doa sangat dibutuhkan ditengah-tengah keluarga \\
\hline 3 & Seorang pemimpin dalam keluarga sebaiknya adalah seorang pendoa \\
\hline 4 & Ayah bertanggungjawab mendidik anak-anaknya untuk hidup takut akan Tuhan \\
\hline 5 & Ayah harus menjadi teladan bagi anak-anaknya dalam perkataan dan perbuatan \\
\hline 6 & Seorang ayah harus memikirkan keselamatan keluarganya \\
\hline 7 & Setiap hari ayah membacakan Alkitab dan berdoa untuk anak-anaknya \\
\hline
\end{tabular}

Tabel 2. Hasil yang di peroleh

\begin{tabular}{|l|l|l|l|l|l|l|}
\hline No/(\%) & SS & S & R & TS & STS & Jumlah \\
\hline 1 & 27 & 11 & 0 & 2 & 0 & 40 \\
\hline$(\%)$ & $85 \%$ & $5 \%$ & $0 \%$ & $10 \%$ & $0 \%$ & $100 \%$ \\
\hline 2 & 40 & 0 & 0 & 0 & 0 & 40 \\
\hline$(\%)$ & $100 \%$ & $0 \%$ & $0 \%$ & $0 \%$ & $0 \%$ & $100 \%$ \\
\hline 3 & 21 & 18 & 1 & 0 & 0 & 40 \\
\hline$(\%)$ & $55 \%$ & $40 \%$ & $5 \%$ & $\%$ & $0 \%$ & $100 \%$ \\
\hline
\end{tabular}


SHAMAYIM: Jurnal Teologi Dan Pendidikan Kristiani, Vol 1, No 1, 2020

\begin{tabular}{|l|l|l|l|l|l|l|}
\hline 4 & 26 & 14 & 0 & 0 & 0 & 40 \\
\hline$(\%)$ & $80 \%$ & $20 \%$ & $0 \%$ & $0 \%$ & $0 \%$ & $100 \%$ \\
\hline 5 & 27 & 13 & 0 & 0 & 0 & 40 \\
\hline$(\%)$ & $85 \%$ & $15 \%$ & $\%$ & $0 \%$ & $0 \%$ & $100 \%$ \\
\hline 6 & 24 & 15 & 0 & 1 & 0 & 40 \\
\hline$(\%)$ & $70 \%$ & $25 \%$ & $0 \%$ & $5 \%$ & $0 \%$ & $100 \%$ \\
\hline 7 & 19 & 19 & 1 & 1 & 0 & 40 \\
\hline$(\%)$ & $45 \%$ & $45 \%$ & $50 \%$ & $5 \%$ & $0 \%$ & $100 \%$ \\
\hline
\end{tabular}

\begin{tabular}{|l|l|l|l|l|l|l|}
\hline & SS & S & R & TS & STS & Jumlah \\
\hline TOTAL & 124 & 40 & 2 & 4 & 0 & 170 \\
\hline$(\%)$ & $76 \%$ & $20 \%$ & $1,33 \%$ & $2,66 \%$ & $0 \%$ & $100 \%$ \\
\hline
\end{tabular}

Berdasarkan tabel di atas, nilai yang tertinggi 124 poin (76\%) ada pada kolom Sangat Setuju (SS), kemudian Setuju (S) dengan 40 poin (20\%), lalu Ragu-ragu (R) 2 poin $(1,33 \%)$, sedangkan Tidak Setuju (TS), 4 poin $(2,66 \%)$ dan terakhir Sangat Tidak Setuju (STS) nihil (0\%).

Hal ini menunjukkan bahwa sejumlah besar responden memiliki pengertian tentang peran orang tua dalam pendidikan agama Kristen di gereja sebagaimana di buktikan dengan berperannya ayah dengan jumlah prosentasi sebanyak $76 \%$. Karena tidak dapat dipungkiri bahwa dalam menanamkan nilai-nilai pendidikan Kristen pada anak, maka seorang ayah harus memiliki kemampuan untuk membimbing anak dengan nilai-nilai ke Kristenan yang nampak dari kehidupan ayah tersebut.

Tabel 3. Pendidikan Agama Kristen sangat penting ditengah-tengah keluarga, meliputi Peranan Ibu

\begin{tabular}{|l|l|}
\hline 1 & Ibu berperan dalam memelihara perkembangan dan pertumbuhan anak-anaknya \\
\hline 2 & Banyak ibu rumah tangga yang kehilangan fungsinya ditengah-tengah keluarga \\
\hline 3 & Ibu memegang peranan sangat penting bagi kebahagian keluarganya \\
\hline 4 & $\begin{array}{l}\text { Ibu adalah seorang yang mampu memberikan perhatian, kasih sayang, rasa aman, } \\
\text { dan keyakinan }\end{array}$ \\
\hline 5 & $\begin{array}{l}\text { Ibu harus menyediakan waktu khusus untuk anak-anaknya dapat berbincang- } \\
\text { bincang }\end{array}$ \\
\hline 6 & Ibu adalah seorang pendengar dan penolong bagi anak-anaknya \\
\hline 7 & Ibu adalah tokoh pertama yang ditiru anak \\
\hline 8 & Ibu menjadi adalah pribadi yang menjadi kebanggaan anak \\
\hline 9 & Ibu adalah pelayan dalam keluarga \\
\hline
\end{tabular}

Tabel 4. Hasil yang di peroleh

\begin{tabular}{|l|l|l|l|l|l|l|}
\hline No/(\%) & SS & S & R & TS & STS & Jumlah \\
\hline 1 & 23 & 17 & 0 & 0 & 0 & 40 \\
\hline
\end{tabular}


Semuel dan Simon: Peranan Orang Tua Dalam Pendidikan Agama Kristen Terhadap Pertumbuhan Rohani Anak

\begin{tabular}{|l|l|l|l|l|l|l|}
\hline$(\%)$ & $65 \%$ & $35 \%$ & $0 \%$ & $0 \%$ & $0 \%$ & $100 \%$ \\
\hline 2 & 10 & 10 & 11 & 5 & 2 & 40 \\
\hline$(\%)$ & $5 \%$ & $5 \%$ & $55 \%$ & $25 \%$ & $10 \%$ & $100 \%$ \\
\hline 3 & 21 & 18 & 0 & 1 & 0 & 40 \\
\hline$(\%)$ & $55 \%$ & $40 \%$ & $0 \%$ & $5 \%$ & $0 \%$ & $100 \%$ \\
\hline 4 & 25 & 15 & 0 & 0 & 0 & 40 \\
\hline$(\%)$ & $75 \%$ & $25 \%$ & $0 \%$ & $0 \%$ & $0 \%$ & $100 \%$ \\
\hline 5 & 26 & 14 & 0 & 0 & 0 & 40 \\
\hline$(\%)$ & $80 \%$ & $20 \%$ & $0 \%$ & $0 \%$ & $0 \%$ & $100 \%$ \\
\hline 6 & 21 & 19 & 0 & 0 & 0 & 40 \\
\hline$(\%)$ & $55 \%$ & $45 \%$ & $0 \%$ & $0 \%$ & $0 \%$ & $100 \%$ \\
& & & & & & \\
\hline 7 & 19 & 18 & 2 & 1 & 0 & 40 \\
\hline$(\%)$ & $45 \%$ & $40 \%$ & $10 \%$ & $5 \%$ & $0 \%$ & $100 \%$ \\
\hline 8 & 18 & 19 & 3 & 0 & 0 & 40 \\
\hline$(\%)$ & $40 \%$ & $45 \%$ & $15 \%$ & $0 \%$ & $0 \%$ & $100 \%$ \\
\hline 9 & 20 & 16 & 2 & 2 & 0 & 40 \\
\hline$(\%)$ & $50 \%$ & $30 \%$ & $10 \%$ & $10 \%$ & $0 \%$ & $100 \%$ \\
\hline
\end{tabular}

\begin{tabular}{|l|l|l|l|l|l|l|}
\hline & SS & S & R & TS & STS & Jumlah \\
\hline TOTAL & 104 & 67 & 18 & 2 & 0 & 181 \\
\hline$(\%)$ & $54,97 \%$ & $33,33 \%$ & $10,53 \%$ & $1,17 \%$ & $0 \%$ & $100 \%$ \\
\hline
\end{tabular}

Berdasarkan tabel di atas, nilai yang tertinggi Setuju (S)dengan 104 poin $(54,97 \%)$, kemudian 67poin (33,33\%) ada pada kolom Sangat Setuju (SS), lalu Ragu-ragu (RR), 18 poin $(10,53 \%)$, sedangkan Tidak Setuju (TS) 2 poin $(1,17 \%)$, dan terakhir Sangat Tidak Setuju (STS) nihil (0\%).

Hasil ini menunjukkan bahwa sejumlah besar $(54,97 \%)$ ada di kolom Sangat Setuju (SS), hal ini menunjukkan bahwa sejumlah besar responden memiliki pengertian tentang peran orang tua dalam pendidikan agama Kristen berdasarkan Ulangan 6:5-7 di gereja sebagaimana di buktikan dengan peranan seorang ibu dengan jumlah prosentasi cukup besar.

Karena tidak dapat dipungkiri bahwa dalam menanamkan nilai-nilai pendidikan Kristen pada anak, maka seorang ibu memang memiliki kemampuan untuk membimbing anak dengan nilai-nilai ke-kristenan yang nampak dari kehidupan ibu tersebut. Penulis menggaris bawahi bahwa peranan seorang ibu memang adalah tepat dalam pendidikan agama Kristen berdasarkan Ulangan 6:5-7 terhadap pertumbuhan rohani anak. 
Tabel 5. Berdasar U1.6:5-7 orang tua mempunyai tugas sebagai pendidik dan wakil Allah diatas muka bumi ini.

\begin{tabular}{|l|l|}
\hline 1 & Orang tua adalah wakil Allah di atas muka bumi ini \\
\hline 2 & Seorang anak akan bangga apabila mempunyai orang tua yang taat kepada Allah \\
\hline 3 & Orang tua harus mendidik anak berulang-ulang tentang Firman Allah \\
\hline 4 & Orang tua menjadi panutan dalam rasa cinta akan Tuhan Yesus \\
\hline & Orang tua menjadi motivator menanamkan rasa cinta akan Tuhan Yesus \\
\hline
\end{tabular}

Tabel 6. Hasil yang di peroleh

\begin{tabular}{|l|l|l|l|l|l|l|}
\hline No/(\%) & SS & S & R & TS & STS & Jumlah \\
\hline 1 & 27 & 13 & 0 & 0 & 0 & 40 \\
\hline$(\%)$ & $85 \%$ & $15 \%$ & $0 \%$ & $0 \%$ & $0 \%$ & $100 \%$ \\
\hline 2 & 26 & 14 & 0 & 0 & 0 & 40 \\
\hline$(\%)$ & $80 \%$ & $20 \%$ & $0 \%$ & $0 \%$ & $0 \%$ & $100 \%$ \\
\hline 3 & 23 & 17 & 0 & 0 & 0 & 40 \\
\hline$(\%)$ & $65 \%$ & $35 \%$ & $2,08 \%$ & $0 \%$ & $0 \%$ & $100 \%$ \\
\hline 4 & 28 & 12 & 0 & 0 & 0 & 40 \\
\hline$(\%)$ & $90 \%$ & $10 \%$ & $0 \%$ & $0 \%$ & 0 & $100 \%$ \\
\hline 5 & 26 & 14 & 0 & 0 & 0 & 40 \\
\hline$(\%)$ & $80 \%$ & $20 \%$ & $0 \%$ & $60 \%$ & $0 \%$ & $100 \%$ \\
\hline & SS & S & R & TS & STS & Jumlah \\
\hline TOTAL & 90 & 30 & 0 & 0 & 0 & 120 \\
\hline$(\%)$ & $80 \%$ & $20 \%$ & $0 \%$ & $0 \%$ & $0 \%$ & $100 \%$ \\
\hline
\end{tabular}

Berdasarkan tabel di atas, nilai yang tertinggi Sangat Setuju (SS)dengan 90 poin (80\%), kemudian 30 poin (20\%) ada pada kolom Setuju (S), lalu Tidak Setuju (TS),0 poin (0\%), Ragu-ragu (R)0poin (0\%), dan Sangat Tidak Setuju (STS) 0 poin (0\%).

Hasil ini menunjukkan bahwa sejumlah besar (80\%) orang tua (ayah dan ibu) dan peduli dan sangat berperan dalam pendidikan agama Kristen berdasarkan Ulangan 6:5-7 terhadapa pertumbuhan rohani anak. Jelas disini kita dapat melihat bahwa rata-rata responden menaruh perhatian khusus dalam hal pendidikan agama Kristen sebagai landasan untuk meningkatkan kerohanian anak.

Tabel 7. Pertumbuhan rohani anak meliputi bertumbuh dalam pengabdian, bertumbuh dalam iman.

\begin{tabular}{|l|l|}
\hline 1 & Seorang kristen harus bertumbuh menjadi dewasa dalam kerohanian \\
\hline 2 & Seorang anak bertumbuh dalam pengabdian dapat dilihat dari motivasi dan \\
\hline
\end{tabular}


Semuel dan Simon: Peranan Orang Tua Dalam Pendidikan Agama Kristen Terhadap Pertumbuhan Rohani Anak

\begin{tabular}{|l|l|}
\hline & keaktifan dalam ibadah \\
\hline 3 & Pertumbuhan rohani anak tergantung pola pendidikan rohani orang tua \\
\hline 4 & seorang anak bertumbuh dalam iman ditandai dengan ketaatan kepada Allah. \\
\hline
\end{tabular}

Tabel 8. Hasil yang di peroleh

\begin{tabular}{|l|l|l|l|l|l|l|}
\hline $\mathrm{No} /(\%)$ & $\mathrm{SS}$ & $\mathrm{S}$ & $\mathrm{R}$ & $\mathrm{TS}$ & $\mathrm{STS}$ & Jumlah \\
\hline 1 & 13 & 23 & 2 & 2 & 0 & 40 \\
\hline$(\%)$ & $15 \%$ & $65 \%$ & $10 \%$ & $10 \%$ & $0 \%$ & $100 \%$ \\
\hline 2 & 22 & 17 & 1 & 0 & 0 & 40 \\
\hline$(\%)$ & $60 \%$ & $35 \%$ & $5 \%$ & $0 \%$ & $0 \%$ & $100 \%$ \\
\hline 3 & 24 & 16 & 0 & 0 & 0 & 40 \\
\hline$(\%)$ & $70 \%$ & $30 \%$ & $0 \%$ & $0 \%$ & $0 \%$ & $100 \%$ \\
\hline
\end{tabular}

\begin{tabular}{|l|l|l|l|l|l|l|}
\hline & SS & S & R & TS & STS & Jumlah \\
\hline TOTAL & 39 & 26 & 3 & 2 & 0 & 70 \\
\hline$(\%)$ & $48,33 \%$ & $43,33 \%$ & $5 \%$ & $3,34 \%$ & $0 \%$ & $100 \%$ \\
\hline
\end{tabular}

Berdasarkan tabel di atas, nilai yang tertinggi Sangat Setuju (SS)dengan 39 poin (48,33\%), kemudian 26 poin (43,33\%) ada pada kolom Setuju (S), lalu Ragu-ragu (R)3 poin $(5 \%)$ sedangkan, Tidak Setuju (TS),2 poin (3,34\%), dan terakhir Sangat Tidak Setuju (STS) nihil (0\%).

Hasil ini menunjukkan bahwa sejumlah besar $(43,33 \%)$ berada pada kategori sangat setuju dan $(43,33 \%)$ berada pada kategori setuju. Hal ini memberikan gambaran bahwa para orang tua mengakui bahwa peran orang tua dalam pendidikan agama Kristen berdasarkan Ulangan 6:5-7 sangat menolong untuk proses pertumbuhan rohani anak. Ini satu indikasi yang baik, sebab fenomena yang muncul saat-saat ini kebanyakan para orang tua mulai meninggalkan peran mendidik anak berdasarkan nilai-nilai pendidikan agama Kristen.

\section{Kesimpulan}

Pendidikan agama Kristen dalam keluarga memegang peranan sangat penting, sebab keluarga merupakan lembaga pertama dalam kehidupan anak, tempat belajar dan menyatakan dirinya sebagai makhluk sosial. Dalam pendidikan agama Kristen, pertama yang harus mengajar dan mendidik anak-anak sejak kecil adalah pendidikan orang tua, bahwa orang tua diberi tugas dan tanggungjawab oleh Allah untuk mendidik anak-anak untuk hidup takut akan Allah. Hasil penelitian yang menunjukkan bahwa responden yang adalah warga jemaat Gereja Pantekosta di Indonesia Glenmore kabupaten Banyuwangi memilih peran Ayah dalam pendidikan agama Kristen terhadap pertumbuhan rohani anak menunjukkan nilai yang tertinggi yaitu sangat setuju (37\%) dan setuju (57,9\%).

Demikian juga dengan hasil penelitian bahwa peranan Ibu dalam pendidikan agama Kristen adalah pendidikan yang bersifat Kristen serta mendasarkan diri pada Alkitab 
sebagai Firman Allah dan menjadikan Kristus sebagai pusat beritanya mencapai nilai tertinggi yaitu setuju 54,97\% dan 33,33\% ada pada kolom sangat setuju. Demikian juga hasil penelitian bahwa orang tua mempunyai tugas sebagai pendidik dan wakil Allah diatas muka bumi ini, memberikan indikasi bahwa betapa pentingnya peran orang tua dalam pendidikan agama Kristen terhadap pertumbuhan rohani anak. Hal ini dibuktikan dengan hasil penelitian menunjukkan nilai sangat setuju $80 \%$, dan setuju $20 \%$. Penelitian ini juga menghasilkan indikasi bahwa pertumbuhan rohani anak tidak terlepas dari peran orang tua dalam pendidikan agama Kristen, dibuktkan lewat perilaku hidup keKristenan yang nampak pada anak-anak. Hal ini nampak pada hasil penelitian ini, dengan pilihan responden mencapai nilai sangat setuju 48,33\%), dan setuju 43,33\%.

\section{Daftar Pustaka}

Dedy Mulyana. No Metode Penelitian. Bandung: Rosdakarya, 2002.

Ezra Tari \& Talizaro Tafonao. "Pendidikan Anak Dalam Keluarga Berdasarkan Kolose 3:21.” KURIOS (Jurnal Teologi dan Pendidikan Agama Kristen) 5, no. 1 (2019).

Helen Farida Latif. "Pengaruh Pengajaran Dan Persekutuan Terhadap Tingkat Pertumbuhan Rohani Anak Dan Remaja.” EPIGRAPHE: Jurnal Teologi dan Pelayanan Kristiani 1, no. 1 (2017).

I.J. Cairn. Tafsiran Alkitab Ulangan. Jakarta: BPK Gunung Mulia, 1986.

I.R. Sarumpae. Rahasia Mendidik Anak. Bandung: Indonesia Publishing House, 2001.

Josh Mc Dwell. The Father Conecnection. Jakarta: Metanonia Publishing, 2004.

L.Z. Raprap. Seminar Pertumbuhan Gereja. Jakarta: Panitia SPG, 1989.

Ninik Tri Utami. “TINJAUAN TERHADAP PRINSIP-PRINSIP PENGAJARAN ANAK BERDASARKAN ULANGAN 6:1-19.” Logon Zeos Jurnal Teologi Sosial dan Budaya 1, no. 1 (2017).

Riana Udurman Sihombing \& Rahel Rati Sarungallo. "Peranan Orang Tua Dalam Mendewasakan Iman Keluarga Kristen Menurut Ulangan 6:6-9." KERUSSO 4, no. 1 (2019).

Rianto J. A. Metboki. "Peranan Orangtua Kristen Dalam Membentuk Karakter Anak." SESAWI: Jurnal Teologi dan Pendidikan Kristen 1, no. 2 (2020).

Robert R. Boelke. Sejarah Perkembangan Dan Praktek Pendidikan Agama. Jakarta: BPK Gunung Mulia, 1998. 
Rony Kontur. Statistik Praktis. Jakarta: PPM, 2005.

Singgih Gunarsa. Singgih Gunarsa Perkembangan Anak. Jakarta: BPK Gunung Mulia, 1980.

Stott, Jhon. Isu-Isu Global Edisi Revisi. Jakarta: Yayasan Komunikasi Bina Kasih, 2015. Sugiyono. Metode Penelitian. 23rd ed. Bandung: ALFABETA, 2016.

—. Statistika Untuk Penelitian. Cetakan ke. Bandung: ALFABETA, 2014.

Talizaro Tafonao. "PERAN PENDIDIKAN AGAMA KRISTEN DALAM KELUARGA TERHADAP PERILAKU ANAK." Edudikara: Jurnal Pendidikan dan Pembelajaran 3, no. 2 (2018).

Tri Waluyo. "Peran Ayah Dalam Pendidikan Kepada Anak Menurut Ulangan 6:1-9." Jurnal Teologi El-Shadday 7, no. 1 (2020).

Walgito, Bimo. Bimbingan Ditinjau Dari Iman Kristen. Salatiga: Fakultas Psikologi, 1973.

Wiles, Keat J. Keluarga Pada Mulanya Hingga Dalam Tuhan. Semarang: STBI, 1986.

Yos E. Rona. Peranan Anak Dalam Pertumbuhan Geraja. Jakarta: Panitia SPG, 1989.

“Alkitab Penuntun Hidup Berkelimpahan.” Malang: Gandum Mas, 2000. 